\title{
Evaluation of Fluoride Contamination Using GIS in Thirukkazhukundram Block, Tamil Nadu, India
}

\author{
A. Amuthini Sambhavi*, K. Nagamani $\dagger^{* *}$ and B. Gowtham*** \\ *Sathyabama Institute of Science and Technology, Chennai, India \\ **Centre for Remote Sensing and Geo-informatics, Sathyabama Institute of Science and Technology, Chennai, India \\ ***Department of Geology, Presidency College, Chennai, India \\ $\dagger$ Corresponding author: K.Nagamani; nagamani@sathyabama.ac.in
}

Nat. Env. \& Poll. Tech.

Website: www.neptjournal.com

Received: 26-07-2021

Revised: 29-08-2021

Accepted: 03-09-2021

Key Words:

Fluoride contamination

Health hazard

Groundwater

Hydro-geology

\section{ABSTRACT}

The presence of fluoride in the groundwater in the Thirukkazhukundram Block in south India is now becoming an increasingly alarming issue. With the semi-arid climatic conditions, charnockite and gneiss rocks form the basement, contributing to the geology of the study area. The pre-monsoon (August 2016) and post-monsoon (February 2017) fluoride concentrations have an average output of $1.3 \mathrm{mg} . \mathrm{L}^{-1}$ and $0.72 \mathrm{mg} . \mathrm{L}^{-1}$ respectively. As of date, only in Neikuppi, the fluoride contamination is found to be $2 \mathrm{mg} . \mathrm{L}^{-}$ ${ }^{1}$ in pre-monsoon which is beyond the accepted limit as per the WHO standards. Other 29 locations taken up for study have fluoride value fluctuation from $1 \mathrm{mg} \cdot \mathrm{L}^{-1}$ to $2 \mathrm{mg} \cdot \mathrm{L}^{-1}$ in the pre-monsoon and from 0 to $1.5 \mathrm{mg} . \mathrm{L}^{-1}$ in the post-monsoon. The main factor responsible for this fluoride contamination lies in the study area's hydro-geological condition which must be attended to immediately to prevent a public health problem in the future.

\section{INTRODUCTION}

All developing countries across the world depend upon the subsurface lithology water to meet up their consumption needs. The quality of the groundwater has been steadily deteriorating due to normal or anthropogenic means, as it happened in cases of worldwide groundwater fluoride contamination and even in our South Indian Thirukkazhukundram block. Fluorine reacting with rock minerals yield fluoride, which though found as a minor trace element in water are very noxious when their concentration is beyond the acceptable limit. Even when the fluoride concentration is very low below the normal limit, the latent effects disturb the public's health after prolonged intake. Thapa et al. (2009) showed the occurrence of high fluoride in drinking water of the study area, maximum mobilization of fluoride associated with na-h $\mathrm{Co}_{3}$ water type, chemical weathering along with ion-exchange bearing the blueprint of fluoride release, inverse geochemical modeling indicating under-saturation of fluoride, and alkaline aquifer condition accelerates the F-accumulation in groundwater. Kalpana et al. (2018) developed a Fluoride Index for mitigation of geogenic contamination by Managed Aquifer Recharge (FIMAR). Groundwater fluoride contamination could be judged by taking into account the temperature, $\mathrm{pH}$, fluorine-containing minerals solubility, anion exchangeability of the minerals present in the aquifer, the geological and geomorphological texture of the study area through which the water is drained, and also the time of contact with a specific lithological unit (Thapa et al. 2009). To avoid dental cavities and mineralization of bone and formation of teeth enamel, a small amount of fluoride is always required. (Thapa et al. 2009). Overconsumption of fluoride causes dental fluorosis, skeletal fluorosis, and nonskeletal fluorosis in humans (WHO 2006). As per WHO, $0.5 \mathrm{mg} . \mathrm{L}^{-1}$ is apt to stop dental fluorosis. Fluoride's desirable limit is $1 \mathrm{mg} . \mathrm{L}^{-1}$ and the allowed limit is $1.5 \mathrm{mg} . \mathrm{L}^{-1}$ as per BIS (1991) and ICMR. High fluoride concentrations in groundwater cause fluorosis in rural, dry, and semi-arid regions, areas with granite and gneiss, and advanced stages of groundwater development (Handa 1988, Balkema et al. 2013, Handa 1975, Narasayya 1970, CSME 1997, Garg et al. 2008, Tchobanoglous \& Burton 1995, Saha 2015, Jothivenkatachalam et al. 2010, Ramesh \& Soorta 2012, Dar et al. 2011, Balakrishnan et al. 2008, Kamalanandhini et al. 2016, Senthilkumar \& Elango 2013, Mondal et al. 2008, Rao et al. 1997, Rama et al. 1982, Whitehead et al. 2009, PHED 2009, Ghazavi et al. 2012, Sinha 1986, Jadhav 2012, Mitharwal et al. 2009, Shrestha \& Kazama 2007, Bharadwaj et al. 2011, Saxena \& Ahmed 2001, WHO 2006, Chen Ching et al. 2015).

\section{Study Area}

Groundwater samples collected from 30 locations of the Thirukkazhukundram Block were tested for fluoride contamina- 
tion in the field itself using the color indicator method. This study area belongs to the Kanchipuram district of Tamil Nadu (Fig. 1). The geology of the study area (Fig. 2) has three segregations viz. coastal aeolian deposits, sand, and silt followed by basement charnockite in certain regions and gneiss in certain other parts. Ultrabasic intrusives of the archaean age and charnockites mainly comprise biotite and hornblende and are intruded by amphibolite, dykes of dolorite, and alluvial deposits are the youngest formation consisting of sands and clays and have deposits of quartz and pegmatites. The shale and clay of the Gondwana age occur on the bank of the Palar river. The Palar alluvium comprises coarse sands and gravels. The average thickness of alluvium is about $10 \mathrm{~m}$ to $30 \mathrm{~m}$. The general trend of the gneiss is NE-SW direction. During the Jurassic period, Gondwana rocks, sedimentary rocks, faulted troughs, and rugged topography of crystalline 6 rocks, were deposited. The in-situ soils, laterites, and alluvial deposits were deposited along the Palar river during the quarternary period. The geomorphology of the study area (Fig. 3) also provides a clear picture of the subsurface lithology, which helps us understand the underlying soil's water-holding and yielding capacity, as well as their chemical environment and interaction, which plays a vital role in the presence or absence of fluoride and other contaminants. Fig. 4 shows the transport network of the study area.

Groundwater occurs mostly under water table or phreatic conditions in weathered, fractured, jointed, and faulted portions of granitic rocks and under artesian conditions in fractured zones located below impervious hard rocks. The pore spaces developed in the weathered mantle acts as shallow granular aquifers and forms the potential water-bearing zones. The water table is shallow in ayacut regions whereas it is relatively deeper in other regions. The groundwater of the charnockite type is found in shallow depths only when weathering is intense, and it develops much more slowly

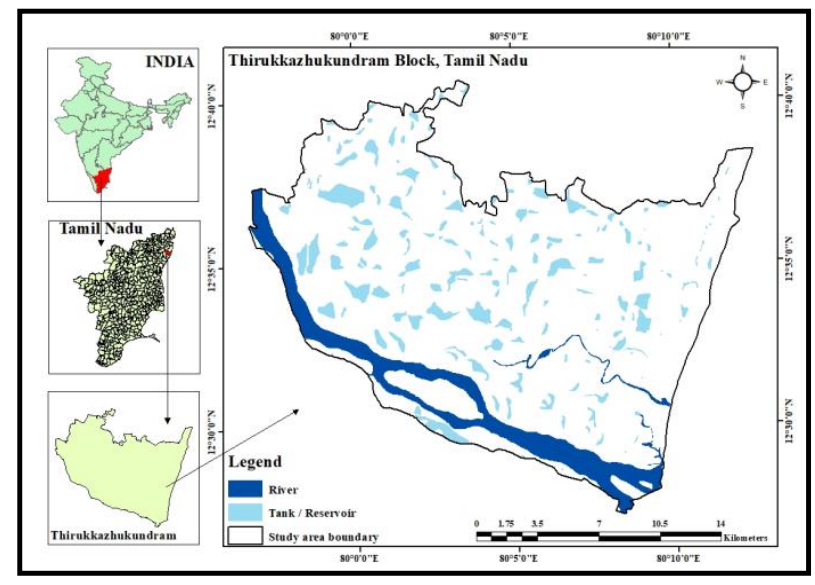

Fig. 1: Location of the study area. than gneissic formations.

The alluvium is the most important formation that carries a significant amount of groundwater. Groundwater is found below the water table or in semi-confined areas. The best aquifer is alluvium, which is primarily made up of stones, gravel, or coarse sand with little or no silt or clay. While silt or clay with a little or no boulders gravel or sand is a very poor aquifer. The thickness of these aquifers ranges from $10 \mathrm{~m}$ to nearly $80 \mathrm{~m}$. One another mode of occurrence of groundwater in the alluvium is in the form of perched aquifers. Groundwater is met in these perched aquifers at a depth of $10 \mathrm{~m}$ from the ground level. In the Gondwana formation area, the groundwater yield is very poor. Groundwater is available under perched water table conditions along the coast. This is quite precious, and it should be used sparingly, as overlapping causes seawater intrusion in the area. The occurrence and movement of groundwater in hard rock formations are restricted to weathered and jointed portions. The intensity of weathering is not uniform and varies from place to place. Generally weathering and fractures are common at shallow depth. The sub-surface conditions can be studied by open-well inventories and by geophysical investigation.

In difficult situations, exploratory boreholes can be used to determine the subsurface conditions. Aquifer test or yield test can also be tried where ever large quantity of groundwater is needed. The SG \& SWRDC has drilled 190 boreholes for investigation purposes throughout the entire district to get a comprehensive idea of the subsurface conditions. The complexity of the geological formations in this district is very well determined by drilling a series of bore wells all along the Palar river course. The thickness of alluvium is about $10 \mathrm{~m}$ near the confluence of the Cheyyar and Palar rivers. The maximum thickness of alluvium ( $30 \mathrm{~m}-40 \mathrm{~m}$ in flood plain area) is noted near Panakattucheri village of Thirukkazhukundram block. Based on the field study carried out and interpretations made from aerial photographs and satellite imageries, favorable

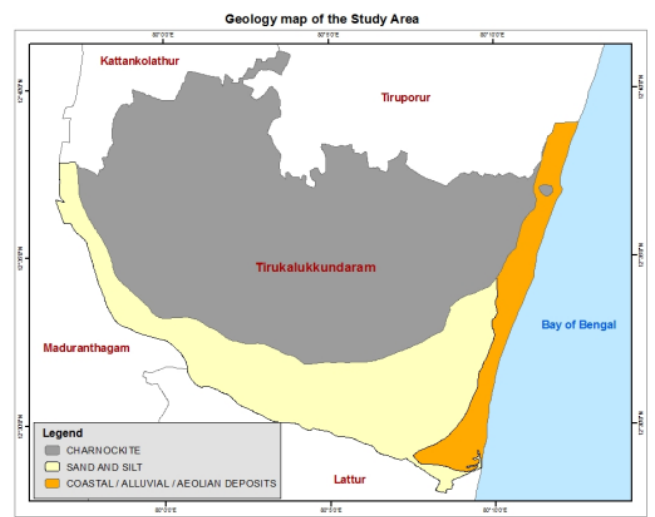

Fig. 2: Geology map of the study area. 
locations are selected for exploratory boreholes. Subsurface hydrogeological characteristics are determined to evaluate the groundwater potential of the area. More than 46 boreholes have been handed over to user agencies like Municipality, TWAD Board and Panchayat Unions, etc., for drinking water purposes. The main aim of this study is to check out the existence and spatial fluctuation of fluoride contagion in pre-monsoon and post-monsoon under surface water, to thoroughly look into the nature of the fluoride concentration and hence to assess the resulting effect on human health on account of fluoride contaminated drinking water.

\section{MATERIALS AND METHODS}

To have clear knowledge regarding the fluoride concentration in groundwater, 30 samples from dug wells and bore wells were collected for examination and were tested in the field using the color indicator method both for pre-monsoon and post-monsoon from the research area, Thirukkazhukundram Block. The outputs were compared with drinking water quality standards as specified in the World health organization (WHO 2006). For every location, before and after the monsoon period, the comparison with the WHO standards was done and the respective spatial maps were prepared. As per WHO standards, fluoride concentration range in groundwater fluoride lies between $1 \mathrm{mg} . \mathrm{L}^{-1}$ (acceptable limit) and $1.5 \mathrm{mg} . \mathrm{L}^{-1}$ (permissible limit). The majority of the study area is unaffected by groundwater fluoride concentration contamination, but in a few areas, contamination has started, posing a serious threat to society.

\section{RESULTS AND DISCUSSION}

Fluoride, pH, EC, and total hardness were keenly studied. The final mean value of fluoride, $\mathrm{pH}, \mathrm{EC}$, and total hardness

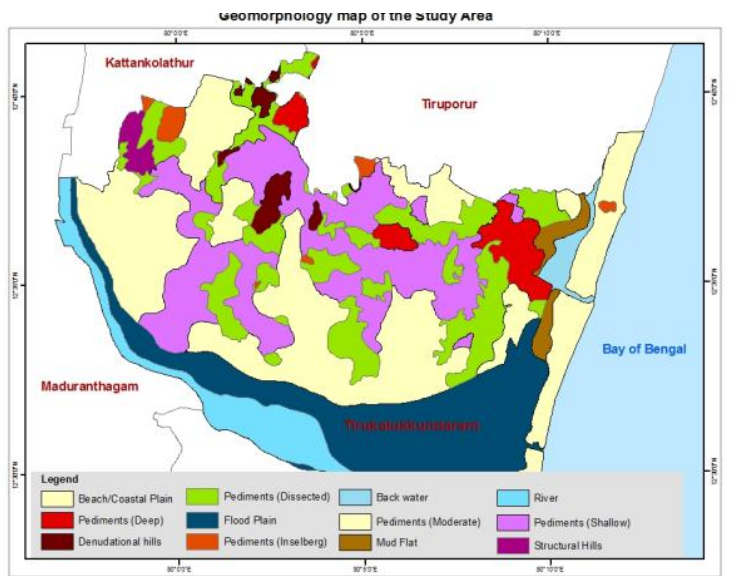

Fig. 3: Geomorphology map of the study area. is provided in Table 1. The groundwater specimen data shows significant variations. Table 1 and Table 2 exhibits the pre-monsoon and post-monsoon period's fluoride distribution and limit of occurrence. Pre-monsoon fluoride varies from 1 to $2 \mathrm{mg} . \mathrm{L}^{-1}$ with a mean value of $1.3 \mathrm{mg} . \mathrm{L}^{-1}$ and post-monsoon fluoride concentration fluctuates from 0 to $1.5 \mathrm{mg} . \mathrm{L}^{-1}$ with a mean value of $0.72 \mathrm{mg} . \mathrm{L}^{-1}$. $\mathrm{pH}$ varies from 7.2 to 8.2 in the pre-monsoon with a mean value of 7.7 and from 7 to 8.1 in the post-monsoon with a mean value of 7.6. EC varies from 616.9 to $2766.5 \mathrm{mg} . \mathrm{L}^{-1}$ in the pre-monsoon with an average of $1310.7 \mathrm{mg} . \mathrm{L}^{-1}$ and from 100.8 to $1219.4 \mathrm{mg} . \mathrm{L}^{-1}$ in the post-monsoon with a mean value of $525.1 \mathrm{mg} . \mathrm{L}^{-1}$. TH varies from 134.541 to $890.1 \mathrm{mg} . \mathrm{L}^{-1}$ in the pre-monsoon with an average limit of $379.1 \mathrm{mg} . \mathrm{L}^{-1}$ and from 25.5 to 344.4 $\mathrm{mg} . \mathrm{L}^{-1}$ in the post-monsoon with a mean value of $144 \mathrm{mg} . \mathrm{L}^{-1}$. The samples were classified into five classes for depicting the frequency distribution (Fig. 5). During the post-monsoon period alone, $17 \%$ of the samples are below the detectable level $\left(<0.25 \mathrm{mg} . \mathrm{L}^{-1}\right)$. Taking the level 0.25-0.5 mg. $\mathrm{L}^{-1}, 33 \%$ of the samples are observed only during the post-monsoon season. When it comes to the $0.75 \mathrm{mg} . \mathrm{L}^{-1}, 37 \%$ and $40 \%$ of the samples are observed during pre- and post-monsoon respectively. Then, for the level $1.25-1.5 \mathrm{mg} . \mathrm{L}^{-1}, 60 \%$ samples are observed during pre-monsoon and $10 \%$ are observed during post-monsoon. Between the two categories, there appears to be a positive trend with fluoride concentration, implying higher pre-monsoon fluoride content in the groundwater of the study area (Fig. 6 and Fig. 7). Also, we found that for value $1.5 \mathrm{mg} . \mathrm{L}^{-1}$, we only observed $3 \%$ of the samples during the pre-monsoon period and nil observation during the post-monsoon period. Up to $0.5-0.75 \mathrm{mg} . \mathrm{L}^{-1}$ level and between 1-1.25 mg. $\mathrm{L}^{-1}$ level, pre-monsoon observations are nil. Only, in Neikuppi, we find fluoride concentration

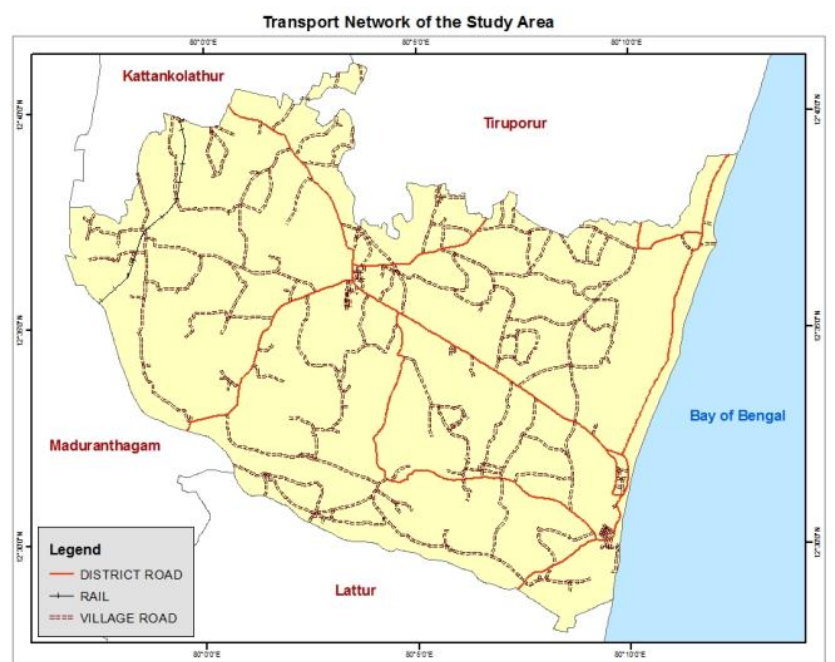

Fig. 4: Transport network of the study area. 
Table 1: Pre-monsoon and post-monsoon concentrations of fluoride $\left(\mathrm{mg} . \mathrm{L}^{-1}\right), \mathrm{pH}, \mathrm{EC}\left(\mathrm{mg} . \mathrm{L}^{-1}\right)$, and total hardness $\left(\mathrm{mg} . \mathrm{L}^{-1}\right)$ in thirty places of groundwater in Thirukkazhukundram block.

\begin{tabular}{|c|c|c|c|c|c|c|c|c|c|}
\hline \multirow[t]{2}{*}{ No. of samples } & \multirow[t]{2}{*}{ Locations } & \multicolumn{4}{|c|}{ Pre-monsoon } & \multicolumn{4}{|c|}{ Post-monsoon } \\
\hline & & $\mathrm{F}$ & $\mathrm{pH}$ & $\mathrm{EC}$ & TH & $\mathrm{F}$ & $\mathrm{pH}$ & $\mathrm{EC}$ & TH \\
\hline 1 & Nenmeli & 1.00 & 8.1 & 746.21 & 224.52 & 0.00 & 7.96 & 272.06 & 98.36 \\
\hline 2 & Thirumani & 1.00 & 7.6 & 650.85 & 214.92 & 0.00 & 7.69 & 215.89 & 70.09 \\
\hline 3 & Alagusamudram & 1.00 & 7.6 & 773.97 & 178.18 & 0.50 & 7.92 & 200.39 & 59.99 \\
\hline 4 & Keerapakkam & 1.00 & 7.8 & 2402.5 & 787.56 & 0.50 & 7.83 & 883.3 & 191.9 \\
\hline 5 & Mosivakkam & 1.00 & 7.5 & 1086.2 & 330.87 & 0.50 & 7.03 & 509.15 & 152.2 \\
\hline 6 & Thazhambedu & 1.00 & 7.8 & 1617.4 & 357.13 & 1.00 & 7.42 & 367.1 & 120.1 \\
\hline 7 & Manapakkam & 1.50 & 7.8 & 2740.2 & 734.32 & 1.00 & 7.84 & 1098.3 & 295.4 \\
\hline 8 & Kuzhipanthandalam & 1.50 & 7.9 & 1108.2 & 340.05 & 1.00 & 7.29 & 241.38 & 58.01 \\
\hline 9 & Pulikundram & 1.50 & 7.8 & 2126.2 & 667.88 & 1.50 & 7.84 & 1219.4 & 344.4 \\
\hline 10 & Mamallapuram & 1.00 & 8.2 & 748.04 & 200.27 & 0.00 & 7.33 & 100.79 & 25.54 \\
\hline 11 & Ponvilayanthakalathur & 1.50 & 7.2 & 2036.5 & 579.61 & 1.00 & 7.65 & 670.08 & 205.8 \\
\hline 12 & Thirukazhukundram & 1.50 & 7.7 & 2766.5 & 890.13 & 1.00 & 7.45 & 1104.8 & 321.8 \\
\hline 13 & Igai & 1.00 & 7.7 & 1084.6 & 316.14 & 0.50 & 7.29 & 512.06 & 149.7 \\
\hline 14 & Navalur & 1.00 & 7.6 & 922.92 & 242.33 & 0.50 & 7.5 & 332.03 & 96.81 \\
\hline 15 & Kadambadi & 1.50 & 7.8 & 676 & 166.99 & 1.00 & 7.61 & 236.99 & 79.16 \\
\hline 16 & Salur & 1.50 & 7.7 & 1011.1 & 260.06 & 1.00 & 7.55 & 373.94 & 109.1 \\
\hline 17 & Pattikadu & 1.50 & 7.7 & 1127 & 338.7 & 1.50 & 8.09 & 312.34 & 102.1 \\
\hline 18 & Thathalur & 1.50 & 7.8 & 977.59 & 273.43 & 0.50 & 7.54 & 466.08 & 130.3 \\
\hline 19 & Amaipakkam & 1.50 & 7.7 & 935.27 & 201.94 & 1.00 & 7.61 & 368 & 116.9 \\
\hline 20 & Kunnathur & 1.50 & 7.9 & 1363.2 & 416.48 & 1.00 & 7.84 & 495.89 & 149.2 \\
\hline 21 & Veerapuram & 1.00 & 7.7 & 1260.7 & 335.67 & 0.50 & 7.33 & 523.38 & 160 \\
\hline 22 & Kilapakkam & 1.50 & 7.7 & 2647.1 & 882.7 & 0.50 & 7.48 & 1079.7 & 270.1 \\
\hline 23 & Neikuppi & 2.00 & 7.8 & 830.55 & 245.27 & 1.50 & 7.35 & 227.18 & 32.89 \\
\hline 24 & Vilagam & 1.50 & 7.9 & 1797.1 & 639.23 & 1.00 & 7.05 & 617.01 & 227.5 \\
\hline 25 & Pandur & 1.50 & 7.6 & 729.48 & 179.48 & 1.00 & 7.94 & 458.73 & 102.6 \\
\hline 26 & Sadurangapatnam & 1.50 & 7.5 & 1186.8 & 282.02 & 0.50 & 7.33 & 621.89 & 121.5 \\
\hline 27 & Lathur & 1.50 & 7.6 & 1523.1 & 431.56 & 0.50 & 7.7 & 551.41 & 108.8 \\
\hline 28 & Irumbilicheri & 1.50 & 7.9 & 1158.9 & 347.82 & 1.00 & 7.57 & 682.96 & 200.4 \\
\hline 29 & Nallathur & 1.50 & 7.3 & 671.01 & 134.48 & 0.00 & 7.34 & 796.62 & 146.3 \\
\hline 30 & Voyalur & 1.00 & 7.3 & 616.94 & 172.57 & 0.00 & 7.53 & 213.83 & 72.98 \\
\hline
\end{tabular}

Table 2: Pre-monsoon and post-monsoon concentrations of fluoride $(\mathrm{mg} / \mathrm{L}) \mathrm{pH}, \mathrm{EC}(\mathrm{mg} / \mathrm{L})$ and total hardness (mg/L) (maximum and mean) in the study place groundwater.

\begin{tabular}{|lllll|}
\hline & Pre-monsoon & & Post-monsoon & Mean \\
\hline F & Max & Mean & Max & 0.72 \\
pH & 2 & 1.3 & 1.5 & 7.6 \\
EC & 8.2 & 7.7 & 8.1 & 525.1 \\
TH & 2767 & 1311 & 1219.4 & 144 \\
\hline
\end{tabular}


in groundwater to be above the permissible level and that particular value is $2 \mathrm{mg} . \mathrm{L}^{-1}$.

\section{The Hydro-Chemical Environment of Thirukkazhuku- ndram's Relation with Groundwater Fluoride}

The relation between environment hydrochemistry and groundwater fluoride is well analyzed. The scatter diagrams in Fig. 8 explain the pre-monsoon and post-monsoon $\mathrm{pH}, \mathrm{EC}$, and TH's relation with fluoride. $\mathrm{PH}, \mathrm{EC}$, and total hardness (TH) administer the correlated plotting. The $\mathrm{pH}$ and fluoride levels have a negative correlation. The main source of fluoride in groundwater is natural contamination, however, the dissolution process is still not well understood (Handa
1975, Saxena \& Ahmed 2001). Fluoride is present in fluorite, granite, gneisses, and pegmatite (Rama 1982), all of which include fluoride. Granite, gneisses, basalts, dolerites, quartzites, pegmatites, hornblende, syenites, biotite, muscovite, fluorite, fluoromica, cryolite, villanite, etc., (Saxena \& Ahmed 2001) are rock varieties that have high fluoride contagion in hard rock terrain. The study area is characterized by three to four layers namely basement gneiss or charnockite hard rock overlain by fractured charnockite or gneissic rocks sedimentary subsurface and on the top we have alluvium. According to Thapa et al. (2009), water level variations, as well as fluoride contamination of groundwater in alluvial zones, are unusual. The majority of the dug wells along with sub-surface water

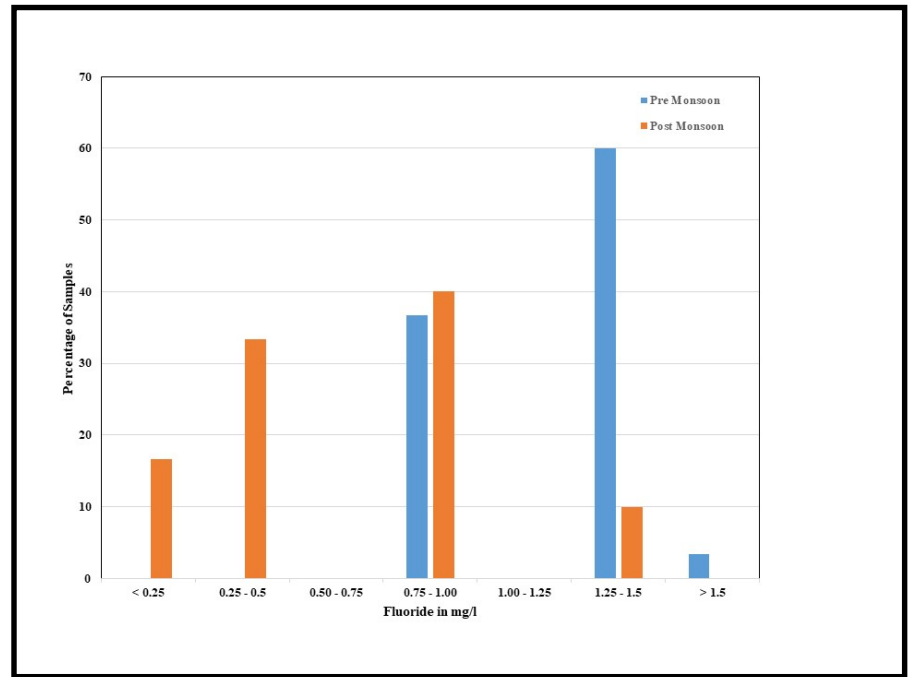

Fig. 5: Frequency distribution of fluoride during pre-monsoon season (August 2016) and post-monsoon season (February 2017).

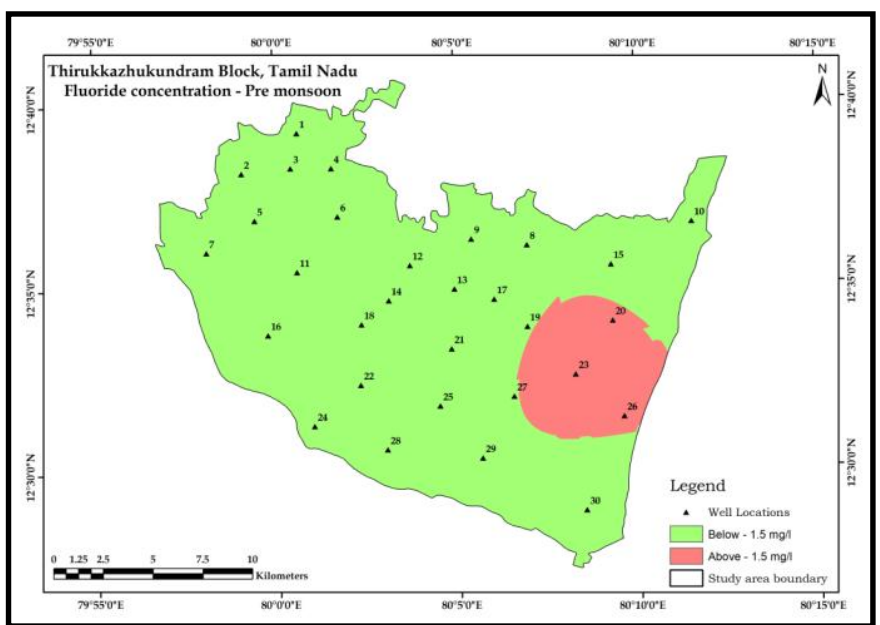

Fig. 6: Spatial map of pre-monsoon groundwater fluoride concentration of the study area. 


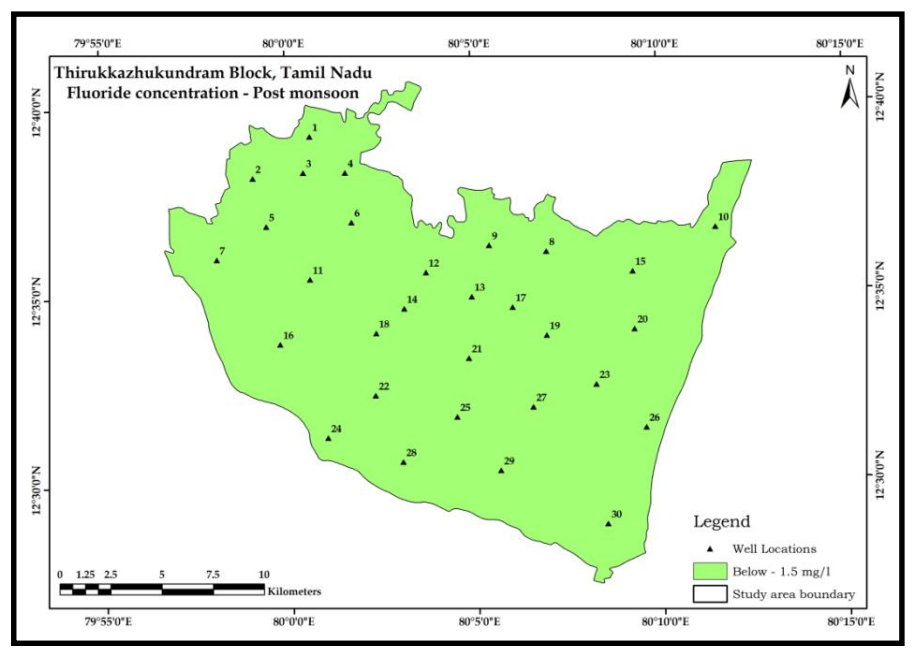

Fig. 7: Spatial map of post-monsoon groundwater fluoride concentration of the study area.
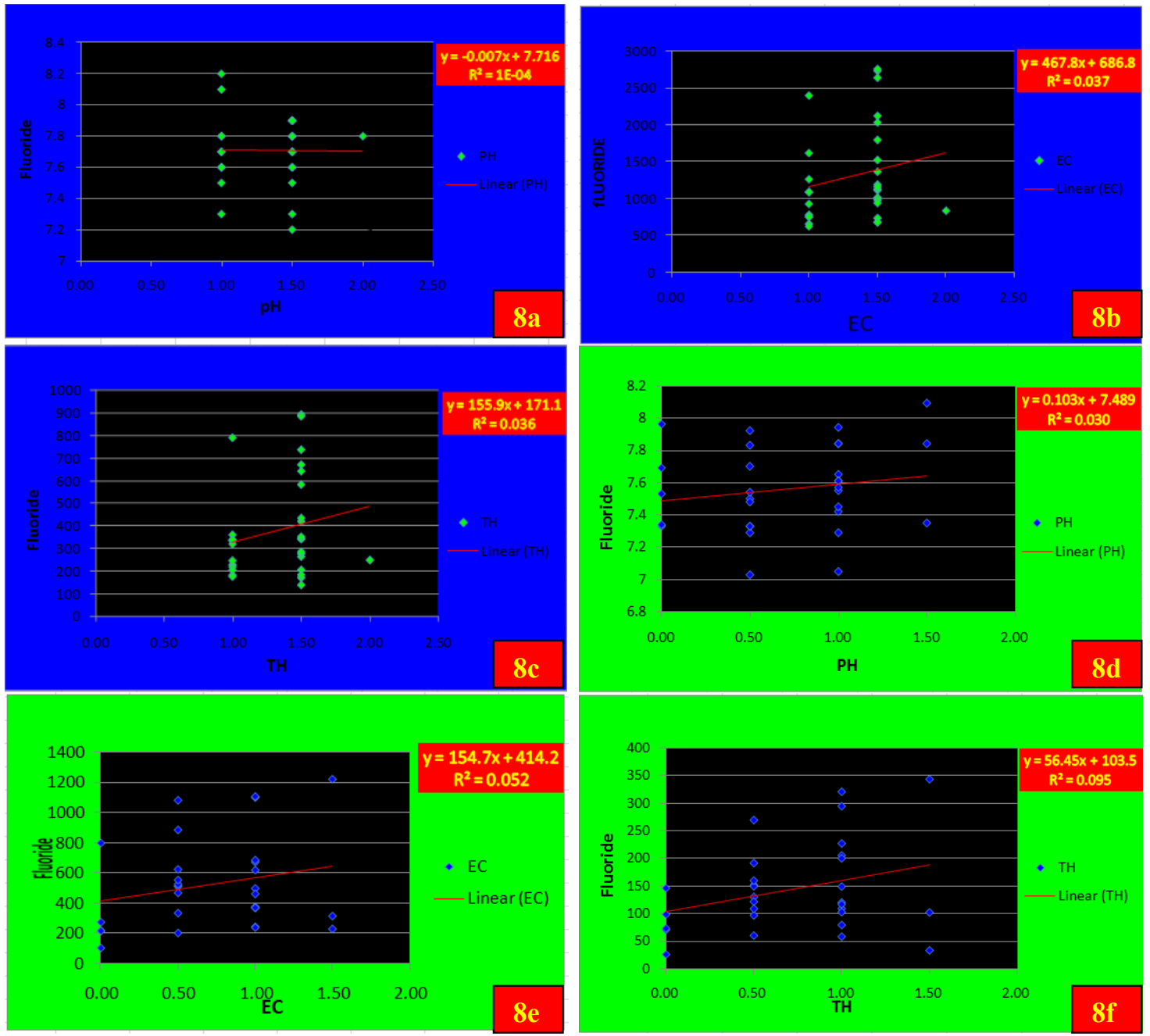

Fig. 8 (a to f): Scatter diagrams showing the relationship of the study area groundwater fluoride and pH, EC and total hardness. 
bodies get depleted. The enrichment process, as well as the rapid decline of the water table, are made more effective by the soil and water reaction, and the gradual and steady casual leaching of fluoride into subterranean flowing water is aided by regional groundwater over-pumping. Because groundwater serves all of the public's domestic needs in the study area, special attention must be paid to fluoride contamination in the groundwater, which could eventually lead to all types of dental and skeletal fluorosis, posing a serious threat to future generations (Kamalanandhini et al. 2016).

\section{Fluoride's Impact on Health Factor}

In terms of the reproductive system (Naseem et al. 2016), there is a decrease in female fertility rates, as well as testosterone reduction, follicle stimulating hormones, and inhibin B quantity reduction in males (OrtizPérez et al. 2003). Fluoride also influences the shape and mobility of sperm in males (Chinoy \& Narayana 1994). When it comes to neurobehavior (Trivedi et al. 2007), intellectual quotient (IQ) and thinking capacity loss occur. Children's mental abilities are impaired. Children's developing brain is subjected to neurotoxicity. (Grandjean \& Landrigan 2006). The central nervous system's energy needs are met by interrupting the glycolysis cycle (ValdezJiménez et al. 2011). Fluoride has an effect on enzyme function, protein structure, brain functioning, hence, defective cognition and memory occurs (Spittle 1994). When it comes to the cardiovascular system, excessive fluoride intake causes oxidative stress, which leads to inflammatory mechanisms, atherosclerosis, vascular stiffness, myocardial cell damage, Bradycardia, abnormal heart rhythms, reduced myocardial function, hypothyroidism, diabetes mellitus, and obesity (Xu et al. 1997). Hypocalcemia and hypercalcemia are also caused by excessive fluoride6 (Nureddin 2018). Loss of mucus layer, hyperaemia, oedema, haemorrhage, and stomach lining rupture are all common gastrointestinal complications (Pratusha et al. 2011), also nausea, vomiting, and stomach pains occur (Nabavi et al. 2013). Thyroid gland structural changes and dysfunctions occur as endocrine system-based effects of abnormal fluoride intake (Kheradpisheh et al. 2018). There is an increase in parathyroid and calcitonin activity, as well as secondary hyperparathyroidism and impaired glucose tolerance (Doull et al. 2006). With respect to the renal system, fluoride concentration abnormality increases the kidney stone risks (Doull et al. 2006). Metabolic, histopathological, and pathological variations in the glomeruli are seen (Bouaziz et al. 2006).

\section{CONCLUSION}

Natural sources constitute the main site of groundwater fluoride in the study area, with a higher concentration during the pre-monsoon season than during the post-monsoon season. The geology, hydrology, and geochemistry of the environment, as well as the weathering of fluoride-containing rocks and significant ups and downs in the water table level, all contribute to the presence of fluoride. Fluoride in groundwater exceeds allowed limits, posing a reasonable concern that is slowly increasing due to delays in the implementation of water treatment schemes. Also, the public relies on groundwater for drinking and other household works. The majority of the public suffers from a lack of proper water supply. Due to the numerous health issues associated with fluoride concentration level abnormalities, care must be taken to ensure that fluoride content does not exceed the permissible limit, and necessary steps must be taken to protect the lives of those who live in this area.

\section{REFERENCES}

Balakrishnan, M., Arul Antony, S., Gunasekaran, S. and Natarajan, R.K. 2008. Impact of dyeing industrial effluents on the groundwater quality in Kancheepuram (India). Indian J. Sci. Technol., 1(7): 1-8.

Balkema, A. A., Rotterdam, M., Chakrabarti, S. and Bhattachary, H.N. 2013. Inferring the hydro-geochemistry of fluoride contamination in Bankura District, West Bengal: A case study. J. Geol. Soc. India, 82: 379-391.

Bharadwaj, V., Dhruv, M. and Singh, S. 2011. Surface and ground-water quality characterization of Deoria district, Ganga Plain, India. Environ. Earth Sci., 63: 383-395.

Bouaziz, H., Ketata, S., Jammoussi, K., Boudawara, T., Ayedi, F., Ellouze, F. and Zeghal, N. 2006. Effects of sodium fluoride on hepatic toxicity in adult mice and their suckling pups. Pestic. Biochem. Physiol., 86: 124-130.

Bureau Of Indian Standards (BIS). 1991. Drinking-Water Specification, (First Revision) IS 10500. India

Calderon, J., Machado, B., Navarro, M., Carrizales, L., Ortiz, M.D. and Diaz-Barriga, F. 2000. Influence of fluoride exposure on reaction time and visuospatial organization in children. Epidemiology, 11(4): S153.

Chen Ching, Y., Heng Lee, Y., Ekhwan Toriman, M., Abdullah, M. and Bin Yatim, B. 2015. Effect of the big flood events on the water quality of the Muar River, Malaysia. Sustain. Water Resour. Manag., 1(2): 97-110.

Chinoy, N.J. and Narayana, M.V. 1994. In vitro fluoride toxicity in human spermatozoa. Reprod. Toxicol., 8: 155-159.

CSME. 1997. Report submitted to NRDMS, DST, GOI, Centre for Study of Man and Environment 1997. http://nrdms.gov.in/ assessment. groundwater.asp.

Dar, M.A., Sankar, K. and Dar, I.A. 2011. Fluorine contamination in groundwater: a major challenge. Environmental Monitoring Assessment, 173(1-4): 955- 68.

Doull, J., Boekelheide, K., Farishian, B.G., Isaacson, R.L., Klotz, J.B., Kumar, J.V. and Thiessen, K.M. 2006. Fluoride in Drinking Water: A Scientific Review of EPA's Standards, Committee on Fluoride in Drinking Water, Board on Environmental Studies and Toxicology, Division on Earth and Life Sciences. National Research Council of the National Academies, National Academies Press, Washington, DC, pp.530.

Garg, D., Kaur, R., Chand, D., Kumar Mehla, S. and Singh, R. 2008. Analysis of water quality of Bharatpur area in post-monsoon season, January 2007. Rasayan J. Chem., 1(4): 743.

Ghazavi, R., Ali, A.B. and Eslamian, S. 2012. Impact of flood spreading on groundwater level variation and groundwater quality in an arid environment. Water Resour. Manag., 26: 1651-1663. 
Grandjean, P. and Landrigan, P.J. 2006. Developmental neurotoxicity of industrial chemicals. Lancet, 368: 2167-2178.

Handa, B.K. 1975. Geochemistry and genesis of fluoride-containing groundwater in India, groundwater, Groundwater, 13: 275-281.

Handa, B.K. 1988. Fluoride occurrence in natural waters in India and its significance. Bhu-Jal News, 3(2): 31-37.

Jadhav, S.D., Sawant, R.S., Godghate, A.G., Patil, S.R. and Patil, R.S. 2012. Assessment of groundwater quality of Ajara Tahsil from Maharashtra. Rasayan J. Chem., 5(2): 246 -249.

Jothivenkatachalam, K., Nithya, A. and Chandra Mohan, S. 2010. Correlation analysis of drinking water quality in and around Perur block of Coimbatore district, Tamil Nadu, India. Rasayan J. Chem., 3(4): 649.

Kalpana, L., Brindha, K. and Elango, L. 2018. FIMAR: A new Fluoride Index for identification of sites to mitigate geogenic contamination by managed aquifer recharge. Chemosphere, 220: 381-390.

Kamalanandhini, M., Nagalakshmi, R., Srividhya, S. and Golda Percy, V.P. 2016. Water quality monitoring in selected observation wells in coastal areas of Chennai and Tiruvallur Districts, Tamil Nadu, India: A case study. Int. J. Pure Appl. Math., 118(20): 4343-4354.

Kheradpisheh, Z., Mirzaei, M., Mahvi, A.H., Mokhtari, M., Azizi, R., Fallahzadeh, H. and Ehrampoush, M.H. 2018. Impact of drinking water fluoride on human thyroid hormones: A case-control study. Sci. Rep., 8(1): 2674

Mitharwal, S., Yadav, R.D. and Angasaria, R.C. 2009. Water quality analysis in Pilani of Jhunjhunu district (Rajasthan): The place of Birla's origin. Rasayan J. Chem., 2(4): 920 -923.

Mondal, N.C., Saxena, V.K. and Singh. V.S. 2008. Occurrence of elevated nitrate in groundwaters of Krishna delta, India. Afr. J. Environ. Sci. Technol., 2(9): 265-271.

Nabavi, S.M., Habtemariam, S., Nabavi, S.F., Sureda, A., Daglia, M., Moghaddam, A.H. and Amani, M.A. 2013. Protective effect of gallic acid isolated from Peltiphyllum peltatum against sodium fluoride-induced oxidative stress in rat's kidney. Mol. Cell. Biochem., 372(1-2): 233-239.

Narasayya, B.L. 1970. Mineralogy of chromite, magnetite, and apatite deposits of the parts of Eastern Ghats, Andhra Pradesh, India. PhD thesis, Andhra University, Andhra Pradesh, India.

Naseem, M., Khurshid, Z., Khan, H.A., Niazi, F., Zohaib, S. and Zafa, M.S. 2016. Oral health challenges in pregnant women: recommendations for a dental care professional. Saudi J. Dent. Res., 7: 138-146.

Nureddin, A. 2018. Adverse effects of fluoride. Adv. Dent. Oral Health, 8(5): 555746.

Ortiz-Pérez, D., Rodríguez-Martínez, M., Martínez, F., Borja-Aburto, V.H., Castelo, J., Grimaldo, J.I., De la Cruz, E., Carrizales, L. and Díaz-Barriga, F. 2003. Fluoride-induced disruption of reproductive hormones in men. Environ. Res., 93: 20-30.
PHED 2009. Report. http://www.wbphed.gov.in/saticpages/ fluoride.html Pratusha, N.G., Banji, O.J.F., Banji, D., Ragini, M. and Pavani, B. 2011. Fluoride toxicity: A harsh reality. Int. Res. J. Pharm., 2(4): 9-85.

Rama, R.N.V. 1982. Geo Chemical Factors Influencing The Distribution Of Fluoride In Rocks, Soils, And Water Sources Of Nalgonda District. Doctoral Thesis, Osmania University, India.

Ramesh, K. and Soorta, V. 2012. Fluoride contamination in drinking water in Palacode Region, Tamil Nadu. Int. J. Res. Chem. Environ., 2(1): 116-123.

Rao, N.S. 1997. The occurrence and behavior of fluoride in the groundwater of the Lower Vamsadhara river basin, India, Hydrol. Sci. J., 6(42): 877-892.

Saha, J. 2015. Groundwater quality of Purulia district: A microlevel study on Purulia-I block, Purulia district, West Bengal. Int. J. Human Resour. Social Sci., 2(7): 40-48.

Saxena, V.K. and Ahmed, S. 2001. Dissolution of fluoride in groundwater: A water-rock interaction study. Environ. Geol., 40: 1084-1087.

Senthilkumar, M. and Elango, L. 2013. Geochemical processes controlling the groundwater quality in the lower Palar river basin, southern India. J. Earth System Sci., 122(2): 419-432.

Shrestha, S. and Kazama, F. 2007. Assessment of surface water quality using multivariate statistical techniques: A case study of the Fuji river basin, Japan. Environ. Model. Software, 22(4): 464-475.

Sinha, R.K. 1986. Industrial Minerals. 2nd edition. Oxford \& FBH, New Delhi, p. 379.

Spittle, B. 1994. Psychopharmacology of fluoride: A review. Int. Clin. Psychopharmacol., 9: 79-82.

Tchobanoglous, G. and Burton, F.L. 1995. Wastewater Engineering: Treatment, Disposal, and Reuse. Tata McGraw-Hill Publishing Company Limited, New Delhi.

Thapa, R., Gupta, S., Kaur, H. and Baski, R. 2019. Assessment of groundwater quality scenario in respect of fluoride and nitrate contamination in and around Gharbar village, Jharkhand, India. HydroResearch, 09: 2-14

Trivedi, M.H., Verna, R.J., Chinoy, N.J., Patel, R.S. and Sathawara, N.G. 2007. Effect of high fluoride water on intelligence of school children in India. Fluoride, 40: 178-183.

Valdez-Jiménez, L., Fregozo, C.S., Beltrán, M.M., Coronado, O.G. and Vega, M.P. 2011. Effects of the fluoride on the central nervous system. Neurologia, 26: 297-300.

Whitehead, P.G., Wilby, R.L., Battarbee, R.W., Kernan, M. and Wade, A.J. 2009. Hydrol. Sci. J., 54(1): 101-123.

WHO. 2006. Guidelines for Drinking Water Quality. 3rd Edition. World Health Organization, Geneva.

Xu, R.Q., Wu, D.Q. and Xu, R.Y. 1997. Relations between environment and endemic fluorosis in a hot region, Inner Mongolia. Fluoride, 302: 6-28. 